\title{
THE MODIFICATION OF THE POLYESTER KNITTED FABRIC FOR MORE ECONOMIC DYEING
}

Marija Kodrić ${ }^{*}$, Dragan Đorđević1 ${ }^{1}$ Sandra Konstantinović1, Mirjana Kostić

(ORIGINAL SCIENTIFIC PAPER) UDC 677.494.674:677.025:677.027

${ }^{1}$ University of Niš, Faculty of Technology, Leskovac, Serbia

2University of Belgrade, Faculty of Technology and Metallurgy, Belgrade, Serbia

This article discusses the process of modification of the polyester knitted fabric as a prerequisite for successful dyeing at a lower temperature and without the presence of the carrier. The processing preceding dyeing, alkali-alcohol hydrolysis with ultrasound, changes the surface morphology causing the peeling and cracks on the surface of polyester fibres of the knitted fabric, decreases the mass and thickness of the knitted fabric, improves the sorption features, capillarity and absorption of water and soaking. The process of dyeing of the modified polyester knitted fabric in the presence of ultrasound at the lower temperature gives much better results than dyeing without ultrasound, and it is very close to the standard process of dyeing of a raw sample at the higher temperature. By increasing the concentration, the level of dye exhaustion per mass unit of the knitted fabric decreases. At the highest applied dye concentrations and the longest dyeing, the biggest dye adsorption happens.
Keywords: dyeing, polyester, disperse dye, alkali-alcohol hydrolysis, ultrasound

\section{Introduction}

The polyester (PES) fibre has a compact structure made by multiple stretching and thermic processing; an extremely hydrophobic character; high electronegative potential and a small number of functional groups capable of reaction with ions and dye molecules. All these features limit the choice of dyes and make the process of dyeing this fibre to be even harder [1].

PES fibres can be dyed in all stages of the production: in the mass in the stage of knitting, as a fibre, in band and filament shape, yarn, fabric or knitted fabrics. The following dyeing methods should be mentioned: the batch process (exhaustion), semi-continual and continual process. The batch method of dyeing can be done at boiling water temperature in the presence of carriers, today known as intensifiers; and at the higher temperature $\left(130^{\circ} \mathrm{C}\right)$ with the increased pressure or the so-called HT (high temperature) method which is mostly in use [2, 3].

Ultrasound with the frequency range of $20-100 \mathrm{kHz}$ is mostly used for increasing the rate of chemical reactions and improving the physical processes such as cleaning, emulsification, degassing and others. The uses of ultrasound enables quicker processes and reaching the same or better results via already existing techniques in less extreme conditions; for example, a lower temperature and lower chemical concentrations. For these reasons, the processes of textile dyeing with ultrasound can be very interesting. The improvements which have been noticed in dyeing the textile with ultrasound are mostly assigned to the phenomena of empty cavities, with mechanical effects which appear: dispersion, degassing and diffusion $[4,5]$.

On the other hand, the alkali processed fabric has better aesthetic appearance and fall and a nice touch; it is comfortable and very similar to silk. Those materials are very hard to differ from silk according to touch and their appearance. Besides these primary effects, processed materials are less prone to peeling; they show better reception of water and dye [6, 7]

This work tends to contribute to the explanations of the impact of the previous modification of the polyester knited fabric to the economical dyeing, i.e. abilities of adsorption of dyes for chemically modified PES fibres in the aqueous environment in the presence of ultrasound waves, at the lower temperature without a carrier. Also, if the exhaustion of dye is large enough, there will be less dyed wastewater and less harm to the environment.

\section{Experiment}

In the experimental part of this work, raw, undyed $100 \%$ polyester (polyethylene terephthalate) knitted fabric was used, which is common in practice with the following characteristics: interlacement interlock, fineness of yarn 9.4 tex, course count $15 \mathrm{~cm}^{-1}$, wale count $16 \mathrm{~cm}^{-1}$ and surface mass $140 \mathrm{~g} / \mathrm{m}^{2}$.

Before dying, the knitted fabric was processed by alcohol solution (ethanol) of sodium hydroxide $80 \mathrm{~g} / \mathrm{dm}^{3}$ for 30 minutes, the ratio of the dyebath was $1: 130$ and the temperature of the process was $20^{\circ} \mathrm{C}$. During this process, the

\footnotetext{
* Author address: Marija Kodrić, Faculty of Technology, University of Nis, 
solution with the substrate (knitted fabric) was exposed to ultrasound waves of $200 \mathrm{kHz}$ and the power of $50 \mathrm{~W}$ (apparatus Elac Ultrasonic Laboratory Reactor URS 1000) all the time.

Dyeing of this modified PES knitted fabric was performed by the disperse dye C.I. Disperse Red 60 (DR60), molecular formula $\mathrm{C}_{20} \mathrm{H}_{13} \mathrm{NO}_{4}$ and the molar mass of $331.32 \mathrm{~g} / \mathrm{mol}$, at $80{ }^{\circ} \mathrm{C}$, without carriers, in the ultrasound reactor Elac Ultrasonic Laboratory Reactor URS 1000. The frequency of the applied ultrasound oscillations was $200 \mathrm{kHz}$ whereas the power was $50 \mathrm{~W}$. Structural formulas of the applied dye and three-dimensional structure obtained by software modelling (ChemBioDraw Ultra 14.0) as well are shown in Figure 1.

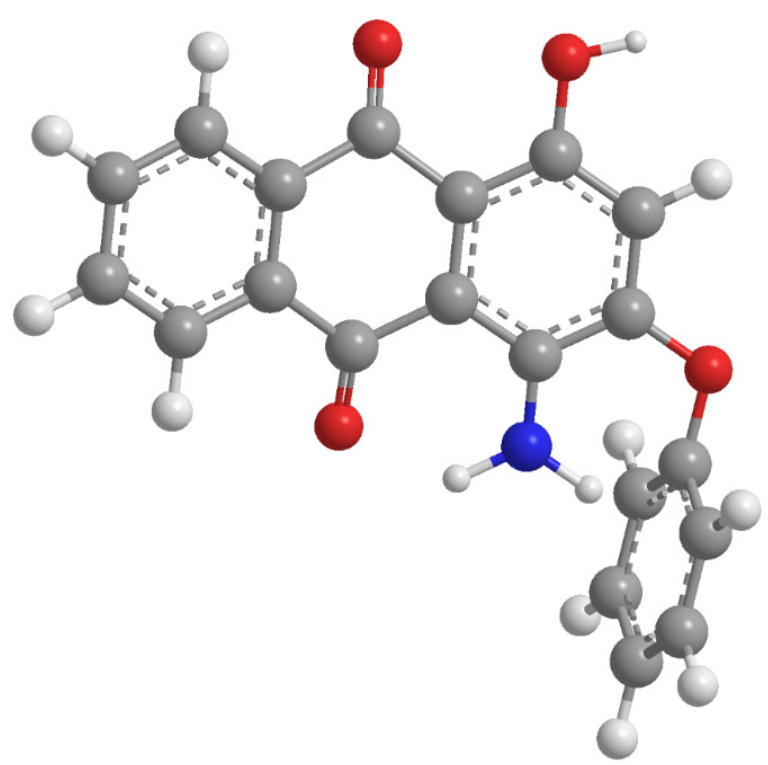

Figure 1. 3D Structure of the applied disperse dye C.I. Disperse Red 60

Precisely, the test of dyeing-adsorption was performed in the way that $1.5 \mathrm{~g}$ of the mass sample of PES knitted fabric was dyed in the solution of the constant volume of $150 \mathrm{~cm}^{3}$; the dye concentration was $50,100,200$ and $400 \mathrm{mg} / \mathrm{dm}^{3}$. In these cases of dyeing, distilled water was used. The time of dyeing with the constant effect of ultrasound was 12, 24, 36, 48 and $60 \mathrm{~min}$. Equilibrium time was 60 min because it was shown that with the longer dyeing there were no significant changes in the level of the dye exhaustion. The aqueous solution of the dye had the dispersing agent (CHT Dispersing agent SMS), $1.5 \mathrm{~g} / \mathrm{dm}^{3}$ and formic acid $(\mathrm{pH}=4.5)$, whereas the temperature of the dye was $80^{\circ} \mathrm{C}$.

For checking the effects of alkali hydrolysis, the following methods were used: the change of the mass (based on the mass differences before and after the process); the power of water absorption -capillarity, SRPS F.S2.042; the power of water absorption, SRPS F.S2.041; optic microscopy, microscope Leica; the thickness of the fabric, SRPS F.S2.021; time of wetting, AATCC TM27-2013.

For determining the concentration of the dye in the solution, UV-VIS spectrophotometry and the apparatus Cary 100 Conc UV-VIS, Varian (absorption maximum on $495 \mathrm{~nm}$ ) were used.
The dye exhaustion [8] was calculated via equation:

Dye Exhaustion $=\frac{C_{0}-C_{t}}{C_{0}} \cdot 100(\%)$

where: $C_{0}$ and $C_{t}, \mathrm{mg} / \mathrm{dm}^{3}$ are the initial and dye concentration in time $t$.

The amount of the adsorbed dye [8] obtained via equation:

$q_{t}=\frac{C_{0}-C_{t}}{w} \cdot V$ and $q_{e}=\frac{C_{0}-C e}{w} \cdot V$

where: $q_{t}(\mathrm{mg} / \mathrm{g})$, the mass of the adsorbed dye per mass unit of the knitted fabric in dying time $t ; q_{e}(\mathrm{mg} / \mathrm{g})$, the mass of the adsorbed dye per mass unit of the knitted fabric in equilibrium; $C_{0}\left(\mathrm{mg} / \mathrm{dm}^{3}\right)$, the initial dye concentration; $C_{t}$ $\left(\mathrm{mg} / \mathrm{dm}^{3}\right)$, the dye concentration in the solution in dyeing time $t ; C_{e}\left(\mathrm{mg} / \mathrm{dm}^{3}\right)$, the equilibrium dye concentration in the solution; $w(\mathrm{~g})$, the mass of the knitted fabric and $V$ $\left(\mathrm{dm}^{3}\right)$, the volume of the solution for dyeing.

\section{Results and discussion}

Alkali-alcoholic hydrolysis of PES knitted fabric

The first thing noticed after the modification of polyester is the mass loss due to hydrolysis of the surface of PES fibres caused by the reaction of alkali. The obtained results confirm that the alkali-alcohol process of the PES knitted fabric causes a certain percentage of the mass loss, Table 1 . In the presence of ultrasound waves hydrolysis leads to the greatest mass loss of PES fibres $(10.7 \%)$, then the same process without ultrasound (6.3\%), as expected.

For example, similar results in the change of mass are noticed after the previous process of PES textile by microwave radiation [9]. Namely, the samples of the PES fabric treated with $1 \%$ solution of caustic soda in the presence of microwave radiation have shown the mass loss, approximately $5.2 \%$. It is established that with the increase of the concentration of alkali, the velocity of hydrolysis increases. Generally, when the polyester fabric is treated in the solution of $\mathrm{NaOH}$ with conventional heating, the mass of the fabric does not decrease fast. However, with microwave radiation, certain fabric shows a greater mass loss for a shorter time, which indicates that microwave radiation increases the velocity of hydrolysis on the surface of fibres.

The feature "thickness" of the textile product can be in direct relation to the mass changes of the knitted fabric, i.e. the insignificant change in the thickness of the knitted fabric is noticed due to alkali hydrolysis, i.e. the processed samples have lower values of this tested parameter, approximately $1-2 \%$ in comparison to the unprocessed sample. Essentially, the mass loss of the knitted fabric leads to its smaller thickness, which happens here, but it should be noted that this tested parameter is affected by deformation or contraction of fibres, i.e. phenomena like swelling and shortening of fibres.

The following properties, on which alkali hydrolysis can have a significant effect, are those which improve moistening such as: water penetration, water absorption or soaking, Table 1. These important properties, especially in hydro- 
phobic materials, certainly deserve our attention because they can contribute to widening of the pallet of products from synthetic fibres by additional, new properties.

Water penetration, along the horizontal and the vertical column is pretty much equal, regarding that the density is almost equal in all directions, so the influence of density and capillaries is excluded. Namely, it is known that capillarity (water penetration) is better in direction with greater density of the yarn which creates the system of capillaries of smaller diameters, which is more suitable for a spontaneous water flow. This explanation is not important for the actual case, regarding the knitted product whose basic constructive unit is loom but not interlacement from crossed threads (yarns) under the right angle, the same as in the waived product. It should be pointed out that the unprocessed sample of the knitted fabric almost does not show water penetration through its structure, i.e. capillarity in both directions of $2.5 \mathrm{~mm}$, whereas in processed samples it is from $25 / 20$ to $32 / 30 \mathrm{~mm}$ (vertical/horizontal), for hydrolysis with and without ultrasound, respectively.

In similar investigation, the ability of the water penetration of the PES fabric, previously processed by the solution of alkali with the simultaneous treatment by microwaves, is increased with the duration of hydrolysis. This happens for two reasons: the first one, hydrophillity of the fabric is improved after the treatment and thereby the affinity of the fibre surface towards water. The second one, the fineness of fibres is decreased, porosity is improved and thereby the input of moisture into the fabric is increased. However, when the mass loss of the fabric is very high, the fabric becomes thin and the distance between the fibres or yarn larger, and then the capillarity is partially decreased [9].

If another type of modification of the surface of PES fibres is used, for example reactions of plasma, then the results of capillarity are very similar. Namely, the polyester fabric treated with corona radiation at different voltage has shown the increased capillarity and hydrophilic properties with the increase of the voltage. The best results are for the voltage of $10 \mathrm{kV}$ [10].

Water absorption from PES knitted fabric confirms that processed samples which go to the direction of increasing of this tested parameter have better results. In comparison to unprocessed sample, the results are better for $20 \%$ (the sample hydrolysed without ultrasound) and $25 \%$ (the sample hydrolysed with ultrasound). In constellation of structural parameters, the density and linear mass of the yarn, the construction of the knitted fabric, as well as surface effects of modification, the explanation for certain phenomena in PES knitted fabric related to all tested sorption properties should be found.

According to Table 1, it can be noticed that modifiedhydrolysed samples of the knitted fabric wet faster. The unprocessed sample of the PES knitted fabric has the slowest wetting, $360 \mathrm{~s}$; the best results, i.e. the most hydrophilic surface of the fabric and then the fastest wetting is hydrolysis in the presence of ultrasound waves, $9 \mathrm{~s}$.
Table 1. Some properties of PES knitted fabric after alkali-alcohol hydrolysis

\begin{tabular}{|c|c|c|c|c|c|c|}
\hline \multirow[t]{2}{*}{ Sample } & \multirow{2}{*}{$\begin{array}{c}\text { Loss } \\
\text { mass } \\
(\%)\end{array}$} & \multirow{2}{*}{$\begin{array}{l}\text { Thickness } \\
\text { (mm) }\end{array}$} & \multirow{2}{*}{$\begin{array}{l}\text { Absorption } \\
\text { water (\%) }\end{array}$} & \multicolumn{2}{|c|}{$\begin{array}{l}\text { Capillarity } \\
(\mathrm{mm})\end{array}$} & \multirow{2}{*}{$\begin{array}{l}\text { Wetting time } \\
\text { (s) }\end{array}$} \\
\hline & & & & Wale & Course & \\
\hline Untreated & - & 0.94 & 330.6 & 2.5 & 2.5 & 360 \\
\hline $\begin{array}{l}\text { Hydrolysis without } \\
\text { ultrasound }\end{array}$ & 6.3 & 0.93 & 395.2 & 25 & 20 & 11 \\
\hline $\begin{array}{l}\text { Hydrolysis with } \\
\text { ultrasound }\end{array}$ & 10.7 & 0.92 & 412.9 & 32 & 30 & 9 \\
\hline
\end{tabular}

Figure 2 shows the images of the surface of PES fibres from the knitted fabric hydrolysed by the alkali-alcoholic solution with the increase of 2016x on the optic microscope. The changes on the surface of fibres are noticeable like micro pores and similar microscopic defects, more in the ultrasound process, Figure 2(b), in comparison to the process without the ultrasound reaction, Figure 2(a). The obtained surface deformations make the fibres be rougher, which changes the touch of the knitted fabric making it similar to the touch of natural fibres, opposite to the characteristic touch of synthetic materials.

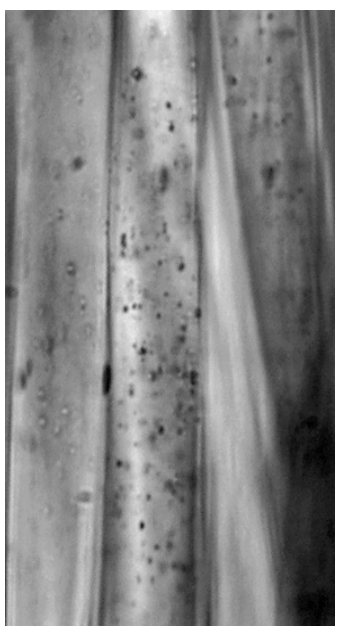

(a)

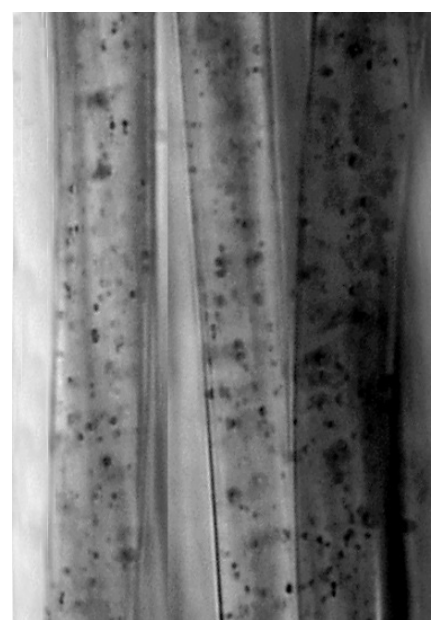

(b)
Figure 2. The appearance of PES fibres after alkali-alcohol hydrolysis without (a) and with ultrasound (b)

Similar phenomena, cracks and micro pores, are noticed on SEM micrographs of the surface of PES fibres after alkali hydrolysis during the 15 and 90-minute process [11]. Polyester fibres are sensitive to alkalis, depending on their ionic character. lonized alkalis, such as caustic soda, affect the outside surface of polyester fibres. It is assumed that these discrete attacks of alkali on ester groups of the surface polymer molecule happen more in amorphous than in crystal areas.

\section{The effects of ultrasound on dyeing}

It is well known that the energy of ultrasound causes degradation of dye aggregates in the solution, leading to the reduction of dye particles in dispersion. The size of dye particles (agglomerate of dye) is decreased due to ultrasound effects; the content of smaller particles is increased, 
whereas the number of bigger particles is significantly decreased [12].

Furthermore, for the analysis of the process of dying of PES fibres, the temperature of glass crossing is very important, which is mostly between $67-80^{\circ} \mathrm{C}$ in polyester [1]. Taking this into consideration, without precise checking of the used fabric sample, dying of modified PES knitted fabric is done at the upper limit of that crossing, at 80 ${ }^{\circ} \mathrm{C}$. The level of dye exhaustion in dyeing of the hydrolysed knitted fabric with ultrasound is much greater than in a similar sample dyed without ultrasound (Table 2), which represents excluded contribution to this additional source of energy, i.e. ultrasound waves. For example, at the lowest and the greatest initial concentration $\left(50\right.$ and $\left.400 \mathrm{mg} / \mathrm{dm}^{3}\right)$, the level of exhaustion after one-hour dyeing of hydrolysed PES knitted fabric with ultrasound waves at $80^{\circ} \mathrm{C}$ are 80.81 and $62.87 \%$, respectively, which is very close to the standard way of dyeing of raw PES knitted fabric at the higher temperature (at $100{ }^{\circ} \mathrm{C}$, in the presence of the carrier and without ultrasound), where the level of exhaustion is slightly higher, 81.69 and $62.87 \%$, respectively. When the same methods of dyeing the raw and previously modified knitted fabric (at $80^{\circ} \mathrm{C}$ ) without ultrasound are compared, the values for the level of exhaustion are different, for example 61.09 and $70.54 \%$, respectively (for the initial concentration of the dye $50 \mathrm{mg} / \mathrm{dm}^{3}$ ), which indirectly shows the significant influence of previous alkali alcohol hydrolysis of PES fibres.

These results can confirm the fact that ultrasound changes the surface morphology of PES fibres in direction of increasing the porosity (during the previous process in the alkali-alcoholic solution), decreases the size of dye particles so that more individual molecules of the disperse dye are present in water, and there are real chances that the applied ultrasound increased the size of amorphous areas in fibres, which gives the possibility to a greater number of dye molecules to diffuse into PES fibres of the knitted fabric. According to the effects which produces on PES fibres, the applied ultrasound should compensate the high temperature of dyeing $\left(100\right.$ or $\left.130{ }^{\circ} \mathrm{C}\right)$. Of course, regarding the structure, PES fibres can be significantly sensitive to the change of temperature, but practically insensitive to the change of temperature of dyeing which is proved by the results of certain testing [13]. On the other hand, there is higher probability that the fibres will be sensitive to the reaction of ultrasound waves the consequence of which can be a large amount of dye molecules inside the fibres.

Since the process of dyeing of modified PES knitted fabric in the presence of ultrasound gave good results, much better than dyeing without ultrasound, and is very close to the standard process of dyeing the raw sample at higher temperature, the display of results in the text that follows will relate exclusively to dyeing of alkali-alcohol hydrolysed PES knitted fabric with ultrasound at the lower temperature $\left(80^{\circ} \mathrm{C}\right)$ instead of usual $\left(100\right.$ or $\left.130^{\circ} \mathrm{C}\right)$.

The influence of the initial concentration of the dye on adsorption-exhaustion during the ultrasound reaction for a different time of dyeing is shown in diagram in Figure 3.
There is the continuity in changes during the increase of the initial concentration of the dye, i.e. with the increase of the concentration, the level of exhaustion of the dye per mass of adsorbent-knitted fabric decreases. With the increase of the concentration of the dye in the solution, at the beginning there is a slightly larger fall of percentage of the exhausted dye, then at the end of dyeing this fall is lower for $10-15 \%$ for each individual time of dyeing from 12 to $60 \mathrm{~min}$.

Table 2. The level of exhaustion of dye on the PES knitted fabric during different methods of dyeing

\begin{tabular}{lcc}
\hline \multicolumn{1}{c}{ Dye recipes (exhaustion method) } & $\begin{array}{c}\text { Dye concentration, } \\
\mathrm{mg} / \mathrm{dm}^{3}\end{array}$ & $\begin{array}{c}\text { Dye exhaustion, } \\
\%\end{array}$ \\
\hline Dyeing of raw PES knitted fabric without ultrasound & 50 & 61.09 \\
$\left(80^{\circ} \mathrm{C}, \mathrm{CHT}\right.$ Dispergator SMS $\left.1.5 \mathrm{~g} / \mathrm{dm}^{3}, \mathrm{pH}=4.5,60 \mathrm{~min}\right)$ & 400 & 43.57 \\
Dyeing of hydrolysed PES knitted fabric without ultrasound & 50 & 70.54 \\
$\left(80^{\circ} \mathrm{C}, \mathrm{CHT}\right.$ Dispergator SMS $\left.1.5 \mathrm{~g} / \mathrm{dm}^{3}, \mathrm{pH}=4.5,60 \mathrm{~min}\right)$ & 400 & 52.47 \\
Dyeing of hydrolysed PES knitted fabric with ultrasound & 50 & 80.81 \\
$\left(80^{\circ} \mathrm{C}, \mathrm{CHT}\right.$ Dispergator SMS $\left.1.5 \mathrm{~g} / \mathrm{dm}^{3}, \mathrm{pH}=4.5,60 \mathrm{~min}\right)$ & 400 & 61.65 \\
Dyeing of raw PES knitted fabric without ultrasound $-\mathrm{standard}$ & 50 & 81.69 \\
procedure from the dye manufacturer & 50 & \\
$\left(100^{\circ} \mathrm{C}\right.$, Sarapol GFD $2 \mathrm{~g} / \mathrm{dm}^{3}, \mathrm{CHT}$ Dispergator SMS $1.5 \mathrm{~g} / \mathrm{dm}^{3}$, & 400 & 62.87 \\
$\mathrm{pH}=4.5,60 \mathrm{~min})$ & &
\end{tabular}

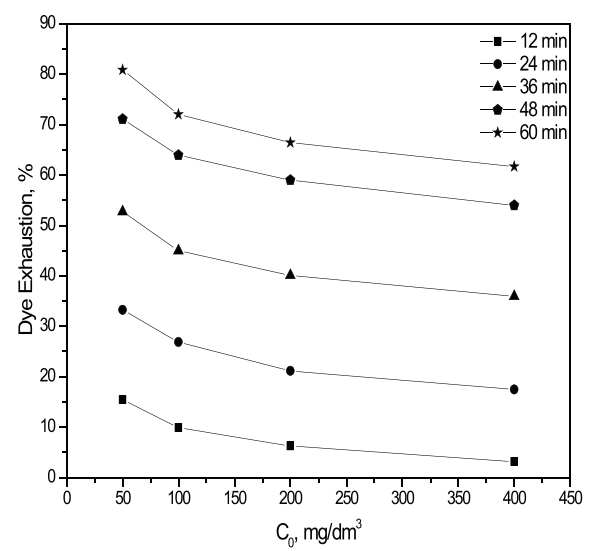

Figure 3. The influence of initial dye on the level of dye exhaustion during ultrasound dyeing of the modified PES knitted fabric

The influence of time or the length of contact between the adsorbate and adsorbent on adsorption-exhaustion of the dye during dyeing with ultrasound, for different initial concentrations of the disperse dye is shown in diagram in Figure 4 . There is the continuity in changes during time, i.e. the longer time carries the greater level of exhaustion. In lower concentrations, at the beginning there is a greater percentage of dye exhaustion and that trend remains during the whole process of dyeing. Linear parts of the curve represent diffusion in the surface layer, whereas parts of the plateau on the curve correspond to diffusion in pores. Similarly, the greater mass loss of the PES fabric due to alkali hydrolysis under microwave radiation causes the greater velocity of dye exhaustion, which means that the previously processed fabric can dye faster than the untreated fabric. Then, simultaneously, the percentage of the 
absorbed dye by PES fabric is larger, which again means that the time of dying can be shorten and the temperature of dyeing reduced [9].

Also, the properties of dyeing PES fabric previously treated by plasma are being improved. With the rise of voltage in the previous process, the amount of dye exhaustion increased from the dyebath during dyeing. This led to the fact that the time of dyeing can be shorten, and the temperature of dyeing decreased, which is generally very important for dyeing of the polyester fabric. After the treatment of fabric by plasma, the disperse dye can absorb fast on the surface of fibres and is easily transmitted inside the fibres, so that the energy of dyeing can be also decreased [10].

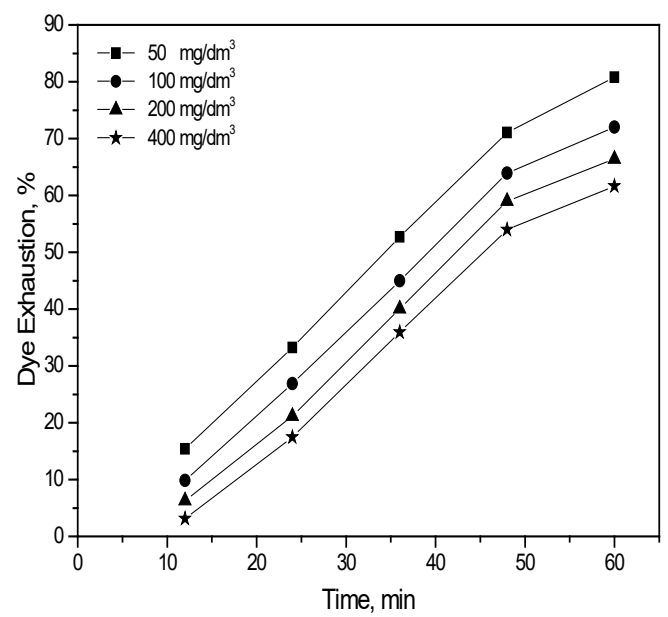

Figure 4. The change of the level of dye exhaustion during ultrasound dying of the modified PES knitted fabric

The fact is that dyeing with ultrasound leads to greater exhaustion and binding of the dye to PES fibres in comparison to dyeing without ultrasound. This proves the positive effect of ultrasound waves on dyeing without the presence of carriers at lower temperatures, which is explained by the effects produced by ultrasound waves.

Besides the previously mentioned, greater dye exhaustion can be interpreted by the famous fact that crystallinity of PES fibres changes during the ultrasound process due to the removal of oligomer from the surface and surface layers, and due to the fact that cavitation of ultrasound can be dislocated macromolecules among microcrystallites increasing the amorphous area, which is supported in other published investigations [4, 5]. In other words, for diffusing of dye molecules inside the fibres, free volume in the inside must be formed. Changed ultrasound helps free volume to easily disappear inside the polymer via thermal moving of molecule chains and from dye molecules that enter this free space. Also, thermal moving of molecule chains is directly connected to the strength of polymer substrate, i.e. the faster diffusion of the dye is achieved in softer and more flexible substrates of polymers, which can be partially the result of ultrasound waves [5].

The results of the change of the adsorbed amount of adsorbate (dye) on the adsorbent (knitted fabric) for different initial concentrations and time of dyeing are shown in diagrams in Figure 5. The continuity in changes during the increase of the initial concentration and during time, i.e. the greater amount of dye in the solution or longer time of dyeing bring a greater amount of the adsorbed dye per mass unit of the adsorbent, i.e. at the greatest applied initial concentrations of the dye and the longest dyeing, the greatest adsorption appears.
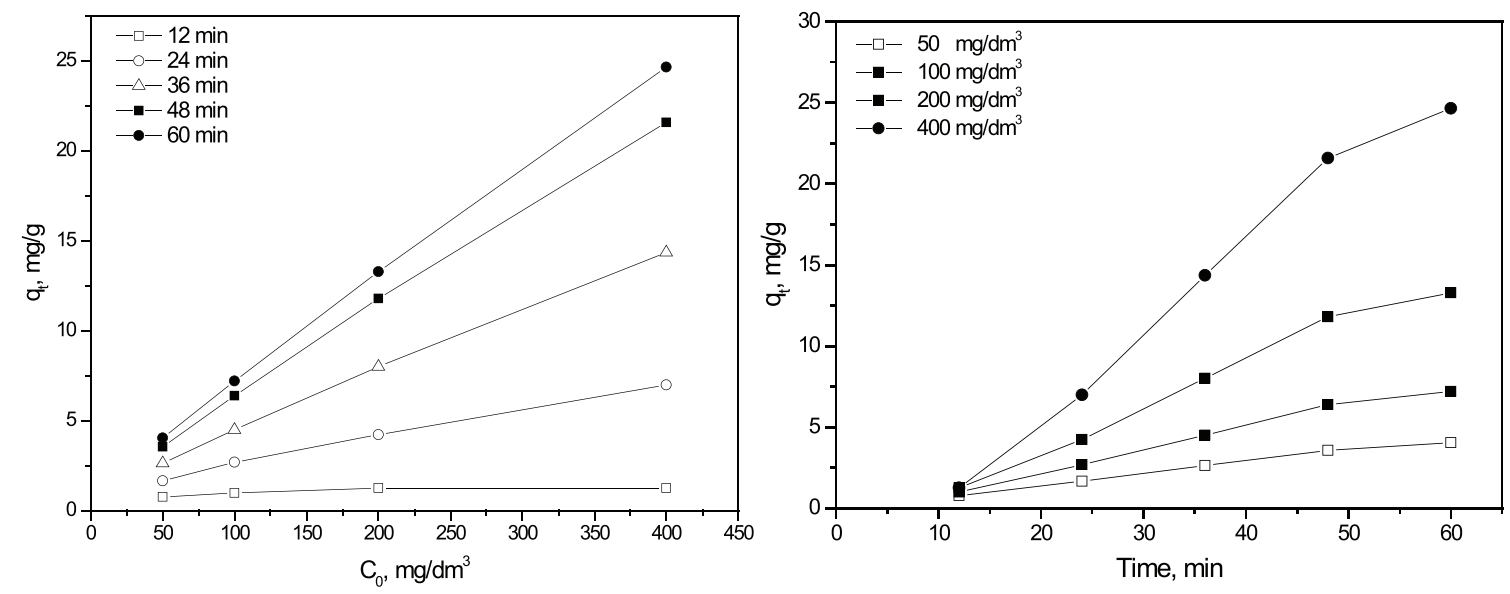

Figure 5. Adsorbed amount of the dye per mass unit of the modified PES knitted fabric in comparison to the initial concentration and time of dyeing 
Since the total surface of fibres is greater than the outside surface, dye molecules will be adsorbed faster during dyeing than the present supplements. However, since the dynamic equilibrium of the solution will be disturbed, the aggregates of the dye will degrade into molecules and again reach the equilibrium in the solution. Adsorption processes will continue until the equilibrium is reached between the concentration of the dye in the solution and the concentration of the dye on the fibre. Regarding that dye molecules have the tendency to form aggregates in the aqueous solution, the applied ultrasound energy will cause breaking of dye aggregates in the solution and decreased the size of dye particles in dispersion, which is the first precondition for better adsorption on the adsorbent [12].

In similar study, the adsorptive behaviour of the disperse dye on the polyester fabric at different temperatures $\left(90,100\right.$ and $\left.110{ }^{\circ} \mathrm{C}\right)$ has been tested. It has been established that the adsorbed amount of the dye per mass unit of the fabric increases with the increase of the dyeing time until the equilibrium state is reached [8].

\section{Conclusion}

Te alkaline process of the polyester knitted fabric leads to the peeling of the surface layer of PES fibres, the diameter of fibres decreases and the configuration of the surface changes. The processed knitted fabric takes the appearance and it is very similar to natural fibres when touched. For better results, it is necessary to carefully choose the content of the bath and the way of the process and work out the phases of the process in order to obtain single peeling of the surface of fibres.

Alkali hydrolysis of the PES knitted fabric in alcohol medium is a relatively simple method for the modification of the surface of polyester fibres, i.e. the textile material from these fibres, with the effects which can be significant for dyeing.

It is shown that dyeing with ultrasound increases the dye exhaustion on the modified PES knitted fabric at lower temperatures. It has been established that dyeing-adsorption depends on the time of contact, the initial concentration of the dye and the presence of ultrasound in hydrolysis and the process of dyeing itself.

Based in the obtained experimental results, the following conclusions can be made:

- Alkali-alcohol hydrolysis with ultrasound changes the surface morphology causing peeling and the appearance of cracks on the surface of fibres of the PES knitted fabric;

- Alkali-alcohol hydrolysis with ultrasound decreases the mass and thickness and fixes sorption properties, capillarity and absorption of water and soaking of the PES knitted fabric as well;

- The process of dyeing of the modified PES knitted fabric in the presence of ultrasound at lower temperatures gives good results, much better than dyeing without ultrasound, and it is very close to the standard process of dyeing of the raw sample at higher temperatures;

- The level of exhaustion of the dye in dyeing of the hy- drolysed knitted fabric with ultrasound is higher than in the same method of dyeing without ultrasound, which represents exclusive contribution of this additional source of energy.

- The levels of dye exhaustion in dyeing of the raw and previously modified knitted fabric without ultrasound are significantly different. They are much better in hydrolysed samples which indirectly shows the significant influence of previously alkali-alcohol hydrolysis of PES fibres.

- By increasing the concentration, the level of dye exhaustion decreases per unit of mass of the adsorbent-knitted fabric;

- At highest applied concentrations of the dye and longest dyeing, the adsorption is greatest.

The results of this work achieved by these effects indicate the possibility of a different approach in the process of dyeing polyester by the disperse dye, for the benefit of greater exhaustion, economy and the protection of the environment.

\section{References}

[1] B. Demirel, A. Yaras, H. Elcicek, Crystallization Behavior of PET Materials, Balıkesir Universitesi Fen Bilimleri Enstitusu Dergisi, 13(1) (2011) 26-35.

[2] S. M. Burkinshaw, Chemical Principles of Synthetic Fibre Dyeing, Blackie Chapman \& Hall, London, 1st edn, 1995, p. 155.

[3] J. Cegarra, P. Puento, J. Valdeperas, The Dyeing of Textile Materials - the Scientific Bases and the Techniques of Application, G.B. Paravia \& C. Torino, Italy, 1992, p. 45.

[4] S. Vajnhandl, A. M. Le Marechal, Ultrasound in textile dyeing and the decolouration/mineralization of textile dyes, Dyes and Pigments, 65(2) (2005) 89-101.

[5] L. Wang, H. F. Zhaoa, J. X. Lin, Studies on the ultrasonicassisted dyeing of poly(trimethylene terephthalate) fabric, Coloration Technology, 126(4) (2010) 243-248.

[6] S. Niu, T. Wakida, S. Ogasawara, H. Fujimatsu, S. Takekoshi, Influence of a Quaternary Ammonium Surfactant on Alkaline Hydrolysis of Heat-Set Poly(ethylene Terephthalate) Fibers, Textile Research Journal, 65(12) (1995) 771-775.

[7] L. Ducoulombier, Z. Dakhli, Z. Lafhaj, Durability of textile facing materials for construction: Implementation of an accelerated aging test by hydrolysis, Journal of Industrial Textiles, 45(6) (2016) 1288-1307.

[8] M. Ghaharpour, A. Rashidi, H. Tayebi, Adsorption Behavior of Disperse Orange 30 on Polyester Fabric, World Applied Sciences Journal, 14(9) (2011) 1291-1295.

[9] W. Xu, C. Yang, Hydrolysis and dyeing of polyester fabric using microwave irradiation, Coloration Technology, 118(5) (2002) 211-214.

[10] W. Xu, X. Liu, Surface modification of polyester fabric by corona discharge irradiation, European Polymer Journal, 39(1) (2003) 199-202.

[11] A. Khoddami, Z. M. Sebdani, S. Mallakpour, Effect of different poly(ethylene terephethalate) hydrolysis to manipulate proper nano-surface structures for fabricating ultra hydrophobic substrate, Journal of textiles and polymers, 1(1) (2013) 36-42.

[12] C. Udrescu, F. Ferrero, M. Periolatto, Ultrasound-assisted 
dyeing of cellulose acetate, Ultrasonics Sonochemistry, 21(4) (2014) 1477-1481.

[13] T.-K. Kima, Y.-A. Sonb, Y.-J. Lim, Thermodynamic parameters of disperse dyeing on several polyester fibers having different molecular structures, Dyes and Pigments, 67(3) (2005) 229-234.

Izvod

\section{MODIFIKACIJA POLIESTARSKE PLETENINE ZA EKONOMIČNIJE BOJENJE}

Marija Kodrić ${ }^{1}$, Dragan Đorđević ${ }^{1}$, Sandra Konstantinović ${ }^{1}$, Mirjana Kostić2

${ }^{1}$ Univerzitet u Nišu, Tehnološki fakultet, Leskovac, Srbija

2Univerzitet u Beogradu, Tehnološko-metalurški fakultet, Beograd, Srbija

U ovom članku se govori o procesu modifikacije poliestarske pletenine kao preduslova za uspešno bojenje na nižim temperaturama i bez prisustva kerijera. Prethodna obrada pre bojenja, alkalno-alkoholna hidroliza sa ultrazvukom, menja površinsku morfologiju, izaziva piling i pukotine na površini poliestarskih vlakana pletenine, smanjuje masu i debljinu, poboljšava svojstva sorpcije, kapilarnost i apsorpciju vode kao i kvašenje pletenine. Proces bojenja modifikovane poliesterske pletenine u prisustvu ultrazvuka na nižim temperaturama daje mnogo bolje rezultate od bojenja bez ultrazvuka i veoma je blizu standardnom procesu bojenja sirovog uzorka na višoj temperaturi. Povećanjem koncentracije smanjuje se iscrpljenje boje po jedinici mase pletenine. Kod najviše primenjene koncentracije boje i najdužeg bojenja, dešava se najveća adsorpcija boje.
(ORIGINALNI NAUČNI RAD) UDK 677.494.674:677.025:677.027

Ključne reči: bojenje, poliestar, disperzna boja, alkalno-alkoholna hidroliza, ultrazvuk. 